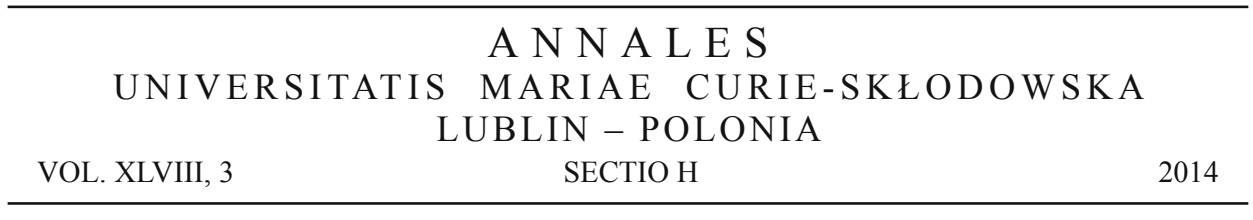

Uniwersytet Mikołaja Kopernika w Toruniu

ANNA PIOTROWSKA

Bitcoin a definicja i funkcje pieniądza

Bitcoin and the definition and functions of money

Słowa kluczowe: bitcoin, kryptowaluta, waluta cyfrowa

Key words: bitcoin, cryptocurrency, digital currency

\title{
Wstęp
}

Kryptowalutę bitcoin można rozpatrywać w kategoriach eksperymentu realizowanego na skalę światową, którego sukces okazał się zaskoczeniem dla wielu uczestników rynku finansowego. Pojawienie się bitcoina stanowi początek nowej ery, w której zaawansowane możliwości technologiczne zmieniły spojrzenie na zasady funkcjonowania systemu finansowego i rozszerzyły pojmowanie kategorii pieniądza. Bitcoin jest wykorzystywany w transakcjach handlowych, przelewach oraz jako aktywa inwestycyjne. Wzrost jego znaczenia w międzynarodowym systemie finansowym wymaga podjęcia bądź kontynuacji działań o charakterze regulacyjnym, kontrolnym, technologicznym oraz społecznym. Stworzenie warunków sprzyjających szerszej społecznej akceptacji i wykorzystaniu bitcoina może w przyszłości ułatwić funkcjonowanie innym kryptowalutom. Pierwszym działaniem, jakie należy podjąć, jest ustalenie relacji między kryptowalutą a pieniądzem. Pozostałe aspekty funkcjonowania bitcoina są pochodną przyjętej definicji tego zjawiska. 


\section{Metodyka badania}

Bitcoin to wyrażony w postaci zapisu elektronicznego instrument płatniczy oraz inwestycyjny funkcjonujący w przestrzeni informatycznej. Wykazuje znaczne podobieństwo do szeroko stosowanego i powszechnie akceptowanego pieniądza elektronicznego. Jego powstanie wpisuje się w obserwowane na świecie odejście od transakcji gotówkowych i powszechną akceptację formy niematerialnej pieniądza. Celem badania jest analiza tej kryptowaluty w zakresie spełnienia kryteriów definicji i funkcji pieniądza formułowanych $\mathrm{w}$ teorii ekonomii, a także przedstawienie aktualnej sytuacji prawnej w wybranych państwach związanej z funkcjonowaniem bitcoina. W pracy przyjęto hipotezę: Kryptowaluta bitcoin pełni funkcje pieniądza. Jej weryfikacja nastąpiła $\mathrm{w}$ drodze krytycznej analizy literatury odnoszącej się do istoty i funkcji pieniądza oraz idei i funkcjonowania kryptowalut. Rozważania wzbogacono prezentacją wybranych wyników z wcześniejszego badania autorki ${ }^{1}$ oraz wywiadem z ekspertem.

\section{Bitcoin - nowe zjawisko na międzynarodowym rynku finansowym}

Nazwa „bitcoin” dotyczy jednostki kryptowaluty, a także systemu informatycznego umożliwiającego dokonywanie płatności czy przelewów w tejże walucie. Określenia „kryptowaluta”, „waluta wirtualna”, „waluta cyfrowa” są powszechnie stosowane, gdyż wskazują na występowanie bitcoina wyłącznie w przestrzeni internetowej, a zarazem na wątpliwość w zakresie kwalifikowania tego zjawiska jako pieniądza czy waluty. Bitcoin zaistniał w przestrzeni internetowej w 2008 roku. Jego twórcy, za którego podaje się osoba lub grupa programistów, ekonomistów, wizjonerów ukrywająca się pod pseudonimem Satoshi Nakamoto, przyświecała idea wyeliminowania pośredników z procesu dokonywania transakcji finansowych [Nakamoto, 2008, s. 1]. Pojawienie się bitcoina stanowi następstwo procesu usieciowienia społeczeństwa i obrotu gospodarczego oraz wyraz dezaprobaty dla instytucji finansowych odpowiedzialnych za wywołanie największego od dziesięcioleci kryzysu finansowego. Komputerowa sieć bitcoin umożliwia kontakt między podmiotami, a zarazem sama pełni funkcję pośrednika finansowego. Jednostką rozliczeniową dla transakcji osoba-osoba jest natomiast kryptowaluta bitcoin.

\footnotetext{
${ }^{1}$ Pionierskie badanie ankietowe przeprowadzone w kwietniu 2013 roku na Uniwersytecie Mikołaja Kopernika w Toruniu przez M. Polasika, A. Piotrowską, R. Kotkowskiego obejmujące globalną populację legalnie działających oferentów internetowych akceptujących bitcoiny, posługujących się językiem angielskim, ogłaszających fakt akceptacji płatności bitcoinami w Internecie w związku z prowadzoną działalnością handlową, usługową lub o charakterze non-profit. W ramach badania uzyskano odpowiedzi od 111 respondentów z 35 krajów.
} 
Umiejętne poruszanie się w powyższej tematyce wymaga znajomości takich pojęć jak ,górnik”, „portfel” i ,,adres bitcoin”, „klucz prywatny” i ,klucz publiczny” oraz „łańcuch bloków”. Górnik to osoba, która działając z innymi uczestnikami sieci w ramach tzw. kopalni, użycza moce obliczeniowe swojego komputera. Wspólnie rozwiązują oni zagadkę matematyczną, a nagrodę stanowią bitcoiny. Mając na uwadze ich wartość, do 21 milionów sztuk systemowo ograniczono ich podaż. Wzrastający cyklicznie stopień trudności wydobycia monet, co wynika z poziomu zaangażowanych mocy obliczeniowych, zapewnia wydobycie określonej liczby bitcoinów w jednostce czasu. Urządzenia obliczeniowe górników, poza wydobyciem, odpowiają również za weryfikację poprawności transakcji kryptowalutą bitcoin w celu eliminacji oszustw [Bradbury, 2013, s. 5-6]. Podsumowując, w systemie bitcoin funkcjonują zdecentralizowani emitenci i zdecentralizowana kontrola obrotu kryptowalutą.

Korzystanie z bitcoina wymaga założenia portfela i umiejętnego, czyli bezpiecznego posługiwania się nim. Wybór dostawcy oprogramowania prowadzącego interakcje z siecią bitcion determinuje funkcjonalność portfela, w którym znajduje się jeden lub więcej adresów bitcoin [Forrester i inni, 2013, s. 38-39]. Adres bitcoin to $\mathrm{z}$ kolei swego rodzaju konto. Jest do niego przypisane pewne saldo kryptowaluty. Adres i jego stan są publicznie dostępne. Anonimowy jest natomiast właściciel adresu i znajdujących się na nim bitcoinów [Wywiad $\mathrm{z}$ ekspertem].

Z chwilą stworzenia danego adresu zostaje do niego na stałe przypisana określona para kluczy - publiczny i prywatny. Są one wykorzystywane w celu przeprowadzania operacji na adresie. Klucz prywatny umożliwia podpisanie transakcji, natomiast autentyczność podpisu można sprawdzić kluczem publicznym [Schurman, 2012, s. 21-22]. Bez względu na wielkość środków na danym adresie klucze te pozostają niezmienne [Wywiad z ekspertem].

Komputery komunikujące się między sobą i tworzące sieć bitcoin prowadzą zbiorową bazę danych. Zawiera ona łańcuchy bloków, czyli współdzielone zapisy zatwierdzonych transakcji. Wartość na adresie bitcoin odnosi się do łańcucha bloków utrzymywanego przez sieć bitcoin [Wywiad z ekspertem].

Liczba użytkowników bitcoin jest bardzo trudna do oszacowania. Można spróbować ją ocenić na podstawie ściągnięć aplikacji Bitcoin-Qt, czyli jednego z podstawowych portfeli bitcoin, którą pobrano około $5,5 \mathrm{mln}$ razy. Polska z liczbą pobrań na poziome około 124 tys. plasuje się na 9 . miejscu na świecie². Dziennie wykonuje się około 60-70 tys. transakcji przy użyciu tej kryptowaluty33. Wzrost zainteresowania bitcoinem dostrzec można również, analizując liczbę oraz strukturę punktów akceptacji płatności w tej kryptowalucie. W kwietniu 2013 roku na podstawie autorskiego badania ankietowego liczbę podmiotów akceptujących bitcoin w e-commerce

\footnotetext{
${ }^{2} \mathrm{http} / /$ sourceforge.net/projects/bitcoin/files/stats/map?dates=2008-11-09+to+2014-05-02 (dostęp: 2.05.2014).

${ }^{3} \mathrm{http}$ ///blockchain.info/pl/charts/n-transactions?timespan=2year\&showDataPoints=true\&daysAverage String $=7 \&$ show_header $=$ true $\&$ scale $=0 \&$ address $=($ dostęp: 02.05 .2014$)$.
} 
oszacowano na 603 [Polasik i inni]. Płatności w tradycyjnych punktach sprzedaży wówczas praktycznie nie występowały. Aktualnie natomiast w skali światowej liczbę samych tylko fizycznych placówek szacuje się na blisko 4,3 tys., w przypadku Polski jest ich około 70 [http://coinmap.org/]. Początkowo podmioty handlowe funkcjonujące $\mathrm{w}$ przestrzeni internetowej przyjmowały płatności w bitcoinach jako zapłatę za oferowane produkty i usługi związane głównie z branżą IT [Polasik i inni]. Aktualnie asortyment dóbr, które można kupić za cyfrową walutę, jest znacznie szerszy. Istnieje także wiele rynków obrotu bitcoinem, w tym polski - Bitcurex. Notowania tej kryptowaluty w początkowym okresie nie przekraczały 1 dolara. Na lokalnym szczycie zaobserwowanym w 2011 roku osiągnęły poziom 32 dolarów, natomiast w 2013 roku było to już ponad 1100 dolarów. Obecnie, w kwietniu 2014 roku, kurs bitcoina to około 450 dolarów ${ }^{4}$.

\section{Definicje i funkcje pieniądza a bitcoin}

\subsection{Definicje i funkcje pieniądza w teorii ekonomii}

Pieniądz nie ma jednej ogólnie przyjętej definicji - zmieniały się one na przestrzeni lat z uwagi na rozwój wymiany handlowej, ewolucję sposobu funkcjonowania gospodarki, przyjęte doktryny ekonomiczne, a przede wszystkim z powodu dóbr, które pełniły funkcję pieniądza. Najpierw były to dobra naturalne i monety mające własną wartość, poprzez papier, aż do pieniądza w postaci zapisu elektronicznego.

M. Friedman definiował pieniądz jako aktywo, które przechowuje siłę nabywczą [Friedman, 1990]. Inni ekonomiści uzupełniają tę definicję, precyzując, iż musi to być aktywo bardzo płynne [Duwendag i inni, 1995, s. 40] i cechować się przewidywalną wartością [Piaszczyński, 2004, s. 14]. J.M. Keynes z kolei uważał, iż „pieniądz, jeśli chodzi o jego najważniejsze własności, stanowi przede wszystkim subtelny środek powiązania teraźniejszości z przyszłością" [Keynes, 1956, s. 376].

Współczesny pieniądz jest symboliczny, gdyż stał się prawnym środkiem płatniczym z mocy ustawy. Zdaniem F.S. Mishkina ,pieniądzem jest to wszystko, co powszechnie akceptuje się jako zapłatę za dobra i usługi, a także jako środek spłaty długu" [Mishkin, 2002, s. 85]. Należy zauważyć, że to władza państwowa nadała współczesnemu pieniądzowi formę i dba o to, aby uzyskał on społeczną akceptację. H. Zadora uważa jednak, że nakaz prawny bez akceptacji społecznej sprawia, że tylko kwestią czasu jest wyeliminowanie $\mathrm{z}$ obiegu danego pieniądza i zastąpienie go pieniądzem darzonym zaufaniem społecznym [Zadora, 2012, s. 46]. W pewnym stopniu potwierdzają ten pogląd relacje między złotym i dolarem w Polsce w latach 70. i 80. Kolejny autor, Z. Polański, odmiennie definiuje współczesny pieniądz,

${ }^{4} \mathrm{http} / / /$ blockchain.info/pl/charts/marketprice?timespan=all\&showDataPoints=true\&daysAverageString $=1 \&$ show_header=true\&scale=0\&address $=$; https://pl.bitstamp.net/ (dostęp: 30.04.2014). 
stwierdzając, że ,jest wytworem świata finansów” [Polański, 1995, s. 24]. Określa go jako „kluczowy element systemu finansowego, integrujący działalność formalnie niezależnych od siebie podmiotów ekonomicznych" [Polański, 1995, s. 25]. Umiejscawia pieniądz bezpośrednio w systemie finansowym, gdyż jego zdaniem ,jedynie system bankowy jest bezpośrednio producentem pieniądza" [Polański, 1995, s. 26], a ponadto pozostaje $\mathrm{w}$ ścisłym związku z innymi ogniwami, takimi jak rynek pieniężny i kapitałowy. Podsumowując tę część rozważań, definicję pieniądza można ograniczyć do stwierdzenia, że jest on czymś powszechnie akceptowanym, łączącym się z zaufaniem wobec jego emitenta i wykorzystywanym w procesie wymiany dóbr i usług.

Istotą pieniądza nie jest jego forma, lecz obszar zastosowań. Teoria ekonomii wskazuje trzy podstawowe funkcje, które powinien pełnić pieniądz: 1) środek wymiany, co oznacza, że pośredniczy w transakcjach handlowych;2) miernik wartości - stanowi wspólną miarę wartości dla wszystkich dóbr, wyrażoną poprzez cenę; 3) środek tezauryzacji, to znaczy jest dobrem, za którego pomocą możemy przechowywać nasze oszczędności i majątek [Gruszecki, 2004, s. 70].

\subsection{Kryptowaluta bitcoin - próba teoretycznego ujęcia zjawiska}

Trudno jest obecnie jednoznacznie zdefiniować bitcoina. W publikacjach poświęconych tej kryptowalucie traktuje się ją jako towar, ekwiwalent pieniądza, nieuregulowany pieniądz cyfrowy, specyficzny rodzaj pieniądza elektronicznego, prawo majątkowe lub instrument inwestycyjny [Tavan, 2013, s. 74; Virtual currency..., 2012, s. 13, 16; Sobolewski, 2014]. W tej części pracy zjawisko to poddano analizie z ekonomicznego punktu widzenia, w kontekście przedstawionych wcześniej definicji i funkcji pieniądza.

Mając na uwadze definicje pieniądza zaproponowane przez F.S. Mishkina oraz H. Zadorę, należy stwierdzić, iż bitcoin nie jest pieniądzem. Nie spełnia on bowiem warunku powszechności akceptowalności. Co prawda, krąg osób stosujących go jako instrument rozliczania płatności stale rośnie, ale użytkownicy bitcoina nadal stanowią niewielką część społeczeństwa.

Ta kryptowaluta nie ma jednego emitenta, ale są nimi niektórzy użytkownicy sieci bitcoin. Nie może więc być mowy o darzeniu zaufaniem konkretnej instytucji mającej na celu zapewnienie bezpieczeństwa obrotu. W przypadku bitcoina zaufanie odnosi się do systemu informatycznego i twórców oprogramowania. Sprawne i bezpieczne działanie systemu bitcoin, czyli oprogramowania i komputerów połączonych w sieć bitcoin, akceptantów oraz giełd tej kryptowaluty, może przyczynić się w przyszłości do wzrostu zaufania i społecznej akceptacji dla bitcoina. Wówczas można byłoby go nazwać pieniądzem.

Pojmowanie przez Z. Polańskiego współczesnego pieniądza jako wytworu świata finansów, a konkretnie systemu bankowego, w kontekście bitcoina oraz innych kryp- 
towalut może być dyskusyjne. W przeszłości pieniądz istniał w świecie pozbawionym instytucji finansowych i można wyobrazić sobie jego funkcjonowanie w przyszłości bez pośrednictwa tychże instytucji.

Bitcoina można także porównać do pieniądza elektronicznego z uwagi na następujące podobieństwa: elektroniczne przechowywanie, wydawanie lub nabywanie w zamian za środki pieniężne, możliwość zapłaty za towary lub usługi, akceptowanie przez podmioty inne niż wydawca. Europejski Bank Centralny zauważył jednak zasadniczą różnicę pomiędzy walutami wirtualnymi a pieniądzem elektronicznym. W systemie pieniądza wirtualnego jednostka rozliczeniowa jest zamieniana na wirtualną, np. bitcoina, a nie jak w przypadku pieniądza elektronicznego na jednostki mające prawny status środka płatniczego, np. euro. W związku z tym EBC sklasyfikował kryptowaluty jako ,specyficznego rodzaju pieniądz elektroniczny, głównie wykorzystywany w transakcjach w świecie internetowym" [Virtual currency..., 2012, s. 16].

Analizując funkcje pieniądza oraz bitcoina, można dojść do następujących wniosków. Bitcoin jest środkiem wymiany, gdyż umożliwia płatności na rzecz bardzo dużej już grupy użytkowników, jak i znaczącej liczby handlowców. Można także uznać, że pełni on funkcję środka tezauryzacji. Wprawdzie duża zmienność kursu jego wymiany w stosunku do walut tradycyjnych uniemożliwia utrzymanie stabilnej wartości oszczędności, ale jego posiadacze godzą się na to i wykorzystują go w tym celu. Obecnie bitcoin nie spełnia natomiast funkcji miernika wartości. Wynika to $\mathrm{z}$ faktu, że nawet podmioty handlowe i użytkownicy płatności w bitcoinach dokonują wyceny w walutach tradycyjnych, a w kryptowalucie rozliczają się po jej aktualnym kursie wymiany. Dopóki ceny produktów nie będą wyrażane wprost w bitcoinach, dopóty funkcja ta nie będzie realizowana. Podsumowując rozważania dotyczące definicji i ekonomicznych funkcji omawianej kryptowaluty, można stwierdzić, iż pełni ona funkcję bardzo zbliżoną do tradycyjnego pieniądza, jednak pieniądzem w świetle teorii ekonomii nie jest.

\section{Bitcoin jako pieniądz przyszłości - wyzwania prawne}

Twórcy bitcoina przyświecała idea uniezależnienia się od systemu bankowego. Sprzeciw wobec instytucji finansowych nie może jednak oznaczać negacji władzy i autorytetu państwa. Zapewnienie bezpieczeństwa obrotu kryptowalutą wymaga stworzenia odpowiednich ram prawnych i instytucjonalnych. Regulacji nie mogą jednak zbyt mocno ingerować w ideę wolności towarzyszącą powstaniu tej kryptowaluty.

Prawne aspekty funkcjonowania bitcoina są dość skomplikowane, ponieważ nie jest on związany z żadnym państwem, a uznanie go przez wszystkie kraje świata jako prawnego środka płatniczego obowiązującego na ich terytorium wydaje się bardzo mało prawdopodobne. Przepisy prawne, które obecnie wykluczają uznanie bitcoina za pieniądz, w przyszłości mogą się zmienić. Być może prawnicy znajdą rozwiązanie tej sytuacji, np. w formie międzynarodowych umów i porozumień dotyczących akceptacji tej formy płatności. 
Dotychczas bitcoin nie został unormowany prawnie ani na poziomie krajowym, ani europejskim. Polska nie zajęła jednoznacznego stanowiska w kwestii zasad opodatkowania tej kryptowaluty. W naszym kraju do tej pory wydano sześć indywidualnych interpretacji podatkowych [Ministerstwo Finansów]. Resort finansów rozważa uznanie walut cyfrowych jako prawa majątkowego [Woźniak, 2013], co w przypadku stwierdzenia, że transakcje nimi są wykonywane w ramach prowadzenia działalności gospodarczej, skutkowałoby obciążenie tych transakcji podatkiem od towarów i usług. Jednak w związku z faktem, że bitcoin jest wykorzystywany jako środek płatniczy, takie rozwiązanie jest nielogiczne i wydaje się sprzeczne z zasadą racjonalnego obrotu gospodarczego.

Wielka Brytania jako jeden z pierwszych krajów zajęła oficjalne stanowisko $\mathrm{w}$ zakresie opodatkowania dochodów uzyskanych z prowadzenia działalności związanej z bitcoinem oraz transakcji z użyciem kryptowalut [Tax treatment..., 2014]. $\mathrm{W}$ przedstawionej interpretacji podatkowej władze brytyjskie uznały bitcoina za „zbywalny instrument finansowy” zwolniony z podatku VAT ${ }^{5}$. Zastosowane przez Wielką Brytanię rozwiązanie jest korzystne dla podatników i sprzyja rozwojowi rynku kryptowalut, a zajęte przez nią stanowisko spowodowało zainicjowanie prac przez Komisję Europejską w ramach Komitetu ds. VAT.

Stworzenie sprzyjających warunków rozwoju kryptowalut i ewoluowania ich w kierunku powszechnie akceptowanego pieniądza poza kwestią VAT wymaga opracowania lub dostosowania regulacji dotyczących podatku dochodowego, prawa dewizowego, ustaw o rachunkowości, usługach płatniczych czy pieniądzu elektronicznym.

\section{Zakończenie}

Bitcoina można traktować jako swego rodzaju realizację idei wprowadzenia ogólnoświatowej waluty, głoszonej przez R. Mundella, twórcy teorii optymalnego obszaru walutowego [Żakowski, 2009]. Co prawda prognozował on zastąpienie walut krajowych jednym, akceptowanym przez wszystkich pieniądzem, ale zapewne miał na myśli powszechne wykorzystanie jednej z funkcjonujących walut krajowych lub wspólnotowych. System bitcoin można także uznać za urzeczywistnienie przewidywań M. Friedmana. Pod koniec lat 90. wyraził on pogląd, że Internet w przyszłości ograniczy rolę rządu w systemie monetarnym i umożliwi stworzenie e-gotówki, która pozwoli na dokonywanie anonimowych płatności [Friedman, 1999].

Przeprowadzone w pracy badanie pozwala stwierdzić, że bitcoina nie można uznać za pieniądz z punktu widzenia teorii ekonomii głównie z powodu braku powszechnej akceptowalności. Postawiona w pracy hipoteza badawcza, że pełni on funkcje pieniądza, została zweryfikowana negatywnie, gdyż nie stanowi on miernika wartości.

${ }^{5}$ Organ podatkowy Wielkiej Brytanii w opublikowanej analizie powołał się na art. 135 ust. 1 lit. d Dyrektywy 2006/112/WE z dnia 28 listopada 2006 r. w sprawie wspólnego systemu podatkowego od wartości dodanej. 
Aby ułatwić rozwój rynku kryptowalut, należałoby objąć je regulacjami ze strony państwa. Być może wówczas spełniałyby one warunki definicji i funkcje pieniądza. Niezależnie jednak od tego, w jaki sposób bitcoin zostanie sklasyfikowany, okazał się on początkiem nowej ery w finansach osobistych. Zmienił się sposób myślenia o pieniądzu, jego emisji i kontroli czy usługach pośrednictwa finansowego.

$$
* * *
$$

Praca była finansowana z grantu Wydziału Nauk Ekonomicznych i Zarządzania Uniwersytetu Mikołaja Kopernika w Toruniu nr 1857-E (2014).

\section{Bibliografia}

1. Bradbury D., The problem with Bitcoin, "Computer Fraud \& Security" 2013, no 11.

2. Duwendag D., Ketterer K.H., Kösters W., Pohl R., Simmert D.B, Teoria pieniadza i polityka pieniężna, Poltext, Warszawa 1995.

3. Forrester D., Solomon M., Bitcoin exposed. Today's complete guide to tomorrow's currency, Grassroots Books, 2013.

4. Friedman M., Monetary Economics, Cambridge Mass, 1990, [za:] W. Piaszczyński, Anatomia pieniadza, Script, Warszawa 2004.

5. Friedman M., wywiad telewizyjny udzielony National Taxpayers Union Foundation, 1999, http:// www.youtube.com/watch? $v=$ mlwxdyLnMXM\&feature=youtu.be (dostęp: 25.04.2014).

6. Gruszecki T., Teoria pieniadza i polityka pieniężna. Rys historyczny i praktyka gospodarcza, Oficyna Ekonomiczna, Kraków 2004.

7. $\mathrm{http} / / /$ blockchain.info/pl/charts/marketprice?timespan=all\&showDataPoints=true\&daysAverageS tring $=1 \&$ show_header $=$ true \&scale $=0 \&$ address $=($ dostęp: 30.04 .2014$)$.

8. http://blockchain.info/pl/charts/n-transactions?timespan=2year\&showDataPoints=true\&daysAver age String $=7 \&$ show_header $=$ true $\&$ scale $=0 \&$ address $=($ dostęp: 02.05 .2014$)$.

9. http://coinmap.org/ (dostęp: 30.04.2014).

10. http://sourceforge.net/projects/bitcoin/files/stats/map?dates=2008-11-09+to+2014-05-02 (dostęp: 2.05.2014).

11. https://pl.bitstamp.net/ (dostęp: 30.04.2014).

12. Keynes J.M., Ogólna teoria zatrudnienia, procentu i pieniadza, Państwowe Wydawnictwo Naukowe, Warszawa 1956.

13. Ministerstwo Finansów, http://sip.mf.gov.pl/sip/index.php (dostęp: 25.04.2014).

14. Mishkin F.S., Ekonomika pieniądza, bankowości i rynków finansowych, PWN, Warszawa 2002.

15. Nakamoto S., Bitcoin: A Peer-to-Peer Electronic Cash System, 2008, https://bitcoin.org/bitcoin. pdf (dostęp: 15.03.2014).

16. Piaszczyński W., Anatomia pieniądza, Script, Warszawa 2004.

17. Polański Z., Pieniadz i system finansowy w Polsce. Lata 1982-1993. Przemiana ustrojowa, PWN, Warszawa 1995.

18. Polasik M., Piotrowska A., Kotkowski R., Waluta wirtualna Bitcoin z perspektywy oferentów internetowych - analiza wstępna, Nauki o Finansach. Prace naukowe Uniwersytetu Ekonomicznego we Wrocławiu, w druku.

19. Schurman K., Bitcoin: free money or fraud?, Hyperink, 2012.

20. Sobolewski P., Nie wierzę w bitcoina, to bańka spekulacyjna, „Parkiet” 2014, nr 15. 
21. Tavan D., A brave, new Bitcoin world?, "The Banker" August 2013.

22. Tax treatment of activities involving Bitcoin and other similar cryptocurrencies, HMRC, Revenue \& Customs Brief 09/14, http://www.hmrc.gov.uk/briefs/vat/brief0914.htm (dostęp: 15.04.2014).

23. Woźniak S., Ministerstwo Finansów, wypowiedź podczas Seminarium Bitcoin Club SGH „Polska potęga bitcoin - szanse i zagrożenia”, Warszawa, 18.12.2013.

24. Virtual Currency Schemes, Europejski Bank Centralny, Frankfurt am Main 2012.

25. Zadora H., Droga do pieniądza współczesnego, [w:] H. Zadora, T. Zieliński, Pieniądz współczesny a kryzysy finansowe, Difin, Warszawa 2012.

26. Żakowski J., Zróbmy jedna światowa walutę!, „Polityka” 2009, nr 12.

\section{Bitcoin and the definition and functions of money}

The appearance of bitcoin is the beginning of a new era in which advanced technological capabilities have changed the perspective on the financial system's functioning rules and have expanded the understanding of the category of money. Bitcoin is used in commercial transactions, transfers and as an investment asset. The establishment of bitcoin is a part of the movement away from cash transactions and the general acceptance of non-material form of money observed around the world. The aim of the study is to analyse the bitcoin cryptocurrency in the scope of the fulfilment of the definition criteria and functions of money formulated in an economic theory, and to present the current legal situation in selected countries relating with its functioning. 